\title{
The Application of Brain-Based Learning in Social Studies Textbook to Inculcate Multicultural Values
}

\author{
Ayi Budi Santosa \\ Department of History Education \\ Universitas Pendidikan Indonesia (UPI) \\ Bandung, Indonesia \\ ayibud@upi.edu
}

\author{
Wildan Insan Fauzi \\ Department of Social Studies Education \\ Universitas Pendidikan Indonesia (UPI) \\ Bandung, Indonesia \\ wildaninsanfauzi@upi.edu
}

\begin{abstract}
Social Studies learning has a role in maintaining the national integration and developing the citizens' characters. The problem is that education hasn't yet succeeded in developing the education of values of whether in the family, school or community. Social Studies book is a learning tool commonly used in schools serving to support the learning process and a means of value inheritance. The macro formulation of this study is "How to inculcate multicultural values in Social Studies textbooks through a brain-based learning approach?". This study applied research and development approach model where the processes refer to the cycle forms based on the research findings of the study which is then developed into a product. The applications of Neuropedagogy in Social Studies books can be: Quotes, timeline, news flash, moral value, behind the figures, mind map, caricature, humor, contemporary issues, if history, and memorizing strategy.
\end{abstract}

Keywords—textbook, multiculturalism, brain-based learning

\section{INTRODUCTION}

The textbook is an important part of the Social Studies learning process and it is acceptably understood because Social Studies textbooks are currently regarded as the most important teaching materials that their existence cannot be separated from the learning process [1] [2]. Textbooks have a great role in the process of inheriting values like multicultural values. A multicultural approach in textbooks should be able to accommodate learners' cultural differences, make use of the culture as a source of content and as a starting point for cultural development, a comprehension of others' cultures, tolerance, arouse nationalism spirit based on single diversity, develop ethical behavior, and be able to harness the students' personal culture as part of their entry-behavior so as to create "equal opportunities for students to achieve [3]. The keywords in multiculturalism are the recognition of differences and appreciation, two words that have often been contrasted.

Brain-based learning is actually a brain-based learning, and it seeks to understand the relationship between the brain and the learning process that leads us to the role of emotion, patterns, meaning, and environment of rhythm, movement, gender, and enrichment [4]. Brain-based learning is the application of neuroscience in education. Barbara K. Given [5] considers that the application of Brain-based learning in education is very important because education is identical to developing a desire to learn, understand learning method, and apply teaching practices based on how the brain actually works. Given develops five learning system frameworks, they are: emotional, social, cognitive, physical, and reflective learning systems. In Given's conception, there is no independent learning system. The actions of each system will affect other systems as part of a larger whole.

\section{LITERATURE REVIEW}

Eric Jansen [4] defines brain-based learning as a way of thinking about the learning process, which is a strategy involvement based on principles derived from an understanding of the brain. Eric Barbara K. Given in her book, Brain-Based Teaching developed five primary learning systems, which are in forms of social, cognitive, physical, and reflective. Such learning system serves to make the learning process more effective and to make both students and teachers feel more excitement in the process of teaching and learning. Given's emotional learning system is a learning system trying to create a conducive class for the residual emotional security and personal relationships for students. The emotional system is personal, self-centered, and internal [5].

The social learning system is a desire to be part of a group, to be respected, and to enjoy the attention of others. The social system focuses on interaction with others or interpersonal experiences. Given's cognitive learning system is the most accepted system because it deals with reading, writing, arithmetic, and all other aspects of academic skill development. The social system focuses on interaction with others or interpersonal experiences [5].

Physical learning system is a learning-oriented on the students' active participation and kinesthetic (movement or action). The physical learning system enjoys challenging academic tasks and here the teachers train inspires and support the active participation to gain the achievement.Thus, the system requires active engagement through meaningful projects. Given's reflective pursuit system requires the students to understand themselves, and this can be developed through various learning trials. Given reminds that there is no standalone learning system. The actions of each system affect other systems as part of a larger whole [5]. 


\section{METHOD}

This research applies research and development approach model. Borg \& Gall [6] defines the research and development model in the field of education as "a process used to develop and validate educational products". The steps in this process frequently refer to the cycle form where research findings are then developed into a product. The development of social studies textbooks based on the findings of this preliminary study is tested in a situation and revise the results of the trials until a model (as a product) can finally be obtained to improve the output.

\section{RESULT AND DISCUSSION}

This section would elaborate ways to apply Barbara Given and Eric Jansen's brain-based learning approach to textbooks so as to help teachers optimize the teaching and learning process.

\section{A. Quotes}

Quotes contain words of wisdom taken from historical figures both nationally and locally. Quotes are an application of the reflective learning system. Reflective thinking leads students to understand themselves [5] The words in historical quotes are expected to provide motivation, to stimulate thinking, and to touch the students' emotions. Quotes can be provided in forms of words of wisdom from local characters, proverbs or rhymes. Multiculturalism also sees how certain cultures can express value to its own members and in these quotes the values are expressed.

Here are the examples of quotes presented in the textbooks:

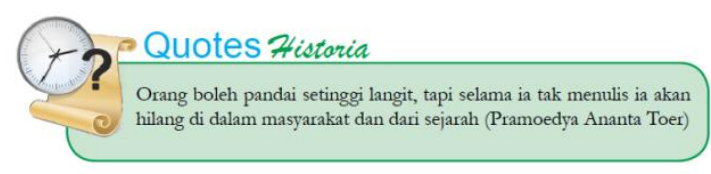

Fig 1. Quotes from Pramoedya Ananta Toer

\section{B. Time Line}

The timeline is included in graphic media. In addition, the timeline is also capable of building students' memory to understand a lesson in a longer time. Longer term memories can help understand an event thoroughly.

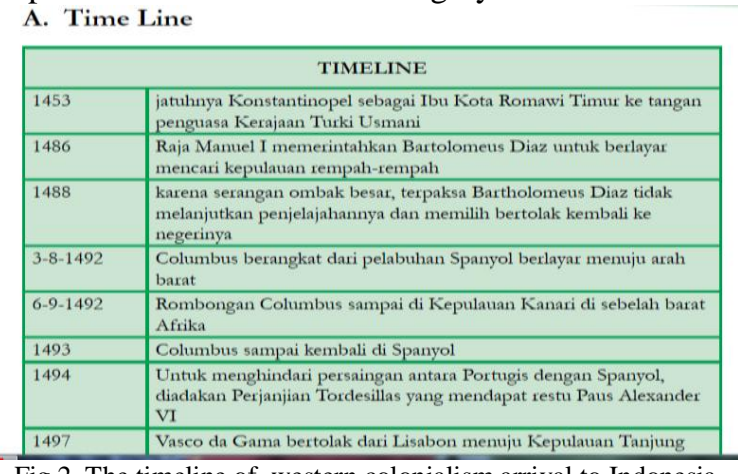

Fig 2. The timeline of western colonialism arrival to Indonesia
Time Line with sequential timeline display can help students understand historical events in real and chronological order so that students are able to build a correct historical understanding of the concept of a certain time. Time Line is medium provideing information in the temporal sphere presented in a timeline. Chronological learning is one of the important goals in social learning because the sequence of events is the key to understanding the past and the present time.

\section{Moral Values of Events and Behind the Figures}

The condition of textbooks whose language is dry and less emotive, loaded with factual contents (number of years, the name of perpetrators, scenes, and course of events), which are described uninterestingly, makes the textbooks contain so few events to be studied and less meaningful that make students are difficult to grasp them. As a result, students become easily saturated in reading the textbooks which are worsened by the condition of dry and less emotive textbooks. Moral values of events and behind the figures are an effort to present a story which stimulates emotion and is efforted to strive in harmony with the student's emotions. The narration on the moral values of event column and behind the characters is directed to build the ability of the learners to identify their personal identity and national identity. The historical figures revealed are local figures and provided to describe the diversity from Sabang to Merauke.

The more effective the identification process that can be developed in social studies learning, the higher the degree of identification can be achieved by the learners. The higher the degree of identification achieved, the stronger the confidence implanted to the learners that he is only able to live in cultural diversity and then defend it [3]. Here are some examples existing in the textbooks:

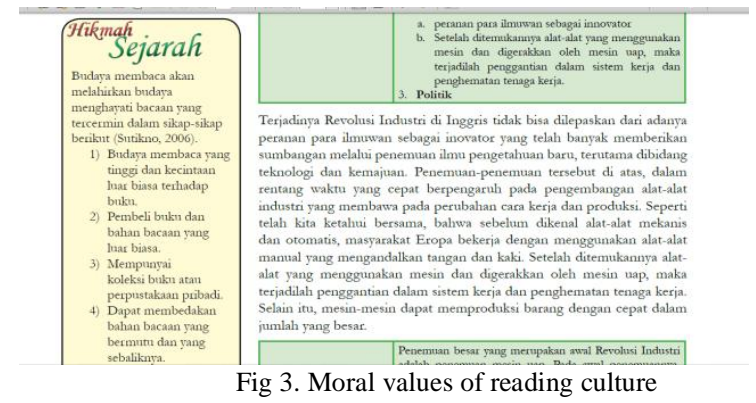

\section{Mind Map}

Mindmap is a creative and effective way of noting which then literally map our thoughts. A mind map is a system of storing and recording the data, and an extraordinary access to extraordinary libraries that actually exist in the amazing brain [7]. Mindmap enables students to construct facts and thoughts in such a way that the natural workings of the brain are involved from the beginning. Here are some mind maps found in the model of textbooks: 


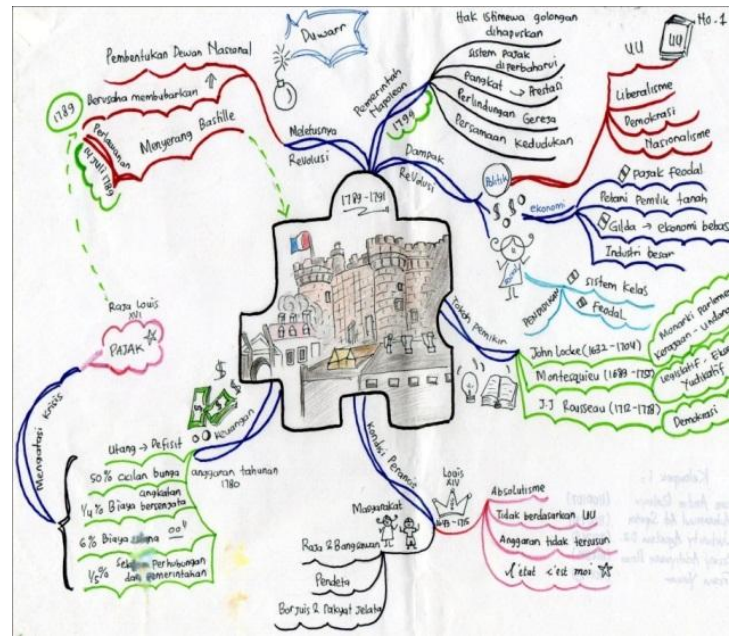

Fig 4. Mindmap of French Revolution material

\section{E. Caricature}

The caricature drawing is a part of a cartoon depicted the fictive form or deformation of particular figures aiming to insinuate, criticize, appeal or suggest its targetted objects. Here are some image samples found in textbook:

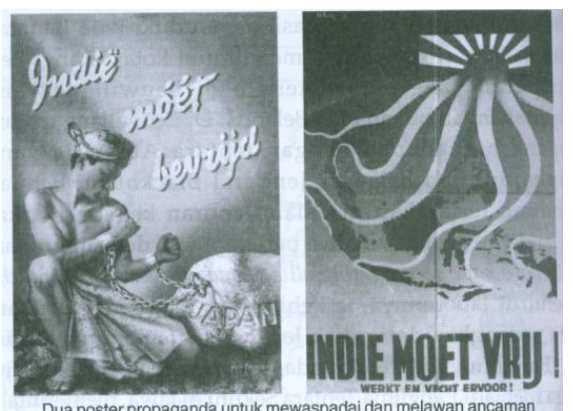

Fig 5. Japanese propaganda

\section{F. Humor}

Emotions encourage personal qualities dramatically affecting students' success or failure in school. Teachers should be careful in recognizing students' body languages and their socio-emotional conditions. Teachers should equalize the learning steps with the students' emotions and to ease tension, the teachers can occasionally use humor but not for sarcasm and humiliation Humor itself contains various stimuli of concern for laughter; peculiarity, impropriety, humor, and innocence. Humor is an integral part of our life, on the one hand, it is one of the ways of the affectionate statement, as one may joke to make others happy, to present a happy atmosphere.

Almost all humor or jokes fundamentally require argumentative thoughts far reaching beyond the limits of the problem posed. The art of humor also has an important role in relation to education, although very few references to it. Humor is essential, and it must be attached to an educator or teacher with all the professional skills they have so that the students will feel as part of the pleasure it generates. The rigid boundaries between teachers and students both concerning with the differences in the level of knowledge and their actions, seem to be fluent or vanishing because of the humor.

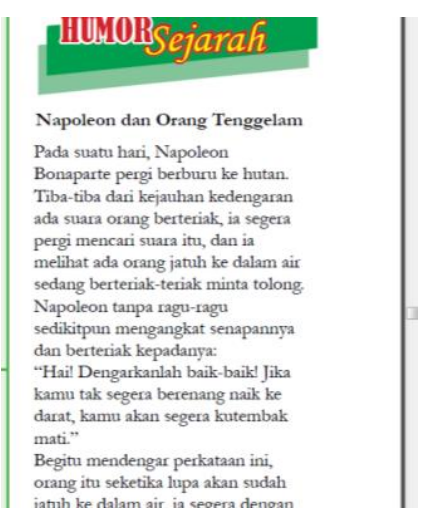

Fig 6. Napoleon Humor

\section{G. Contemporary issues}

Contemporary issues contain controversial and debatable materials. The controversial issues in social studies learning can improve students' critical thinking skills. Students' thinking skills can be trained through thinking learning that is expected to optimize the development of their intellect. This column can be filled to accommodate various events that occur in a smallest local even including local culture. Therefore, social studies textbook materials should not restrict themselves only to national-level events and cultures but also those events and cultures occurring around the learners' cultural environment, other cultural environments, and national ones.

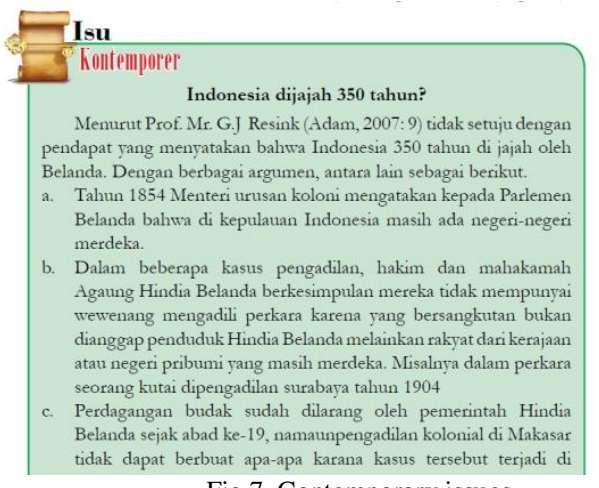

Fig 7. Contemporary issues

\section{H. If History}

If history contains a short question that asks the readers to elaborate the history if what happens is the opposite of the actual reality. This column teaches students to think critically and creatively. Critical thinking is a reflective thinking activity focused on trying to decide what to believe and do. Critical thinking can also be defined as a disciplinary thinking process 
used to assess the truth of things: statements, stories, news, arguments, research, etc. [5].

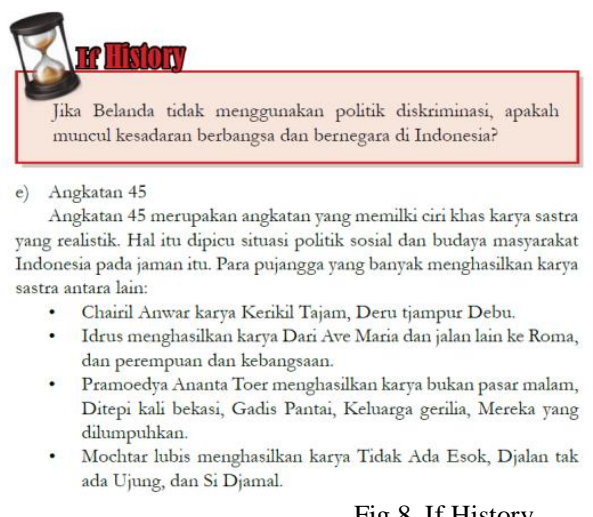

Fig 8. If History

\section{Memorizing Strategy}

One form of the approach developed by Eric Jansen in Brain-Based Learning is memorizing or remembering techniques. The results of the study revealed that different subjects demanded different ways of storing and remembering their information [5]. To strengthen the memory, it is necessary to consider the intake of nutrients in food. Foods that can strengthen human memory include norefinerin (Vitamin A) and milk, adrenaline (to protect and to repair memory, to store sad or pleasant events), acitekolin (long-term memory), lecithin in meat, eggs, and salmon.

\section{CONCLUSION}

This study examines the efforts of applying brainbased learning approach to textbooks. Brain-based teaching is not something new in the world of education, but its application in social studies learning has not done much research in depth. In the last two decades, research on brainbased teaching has grown tremendously, and educators who apply these findings have achieved remarkable results. This study uses a qualitative approach.

The application of Neuropedagogy in social studies textbooks comprise:

1. Quotes (words of wisdom from figures),

2. Time Line (Chronology of historical events),

3. Moral Value (educational values from events and stories),

4. Behind the figures (interesting story and not -muchrevealed facts from the figures containing exemplary value),

5. Mind Map (mapping concepts),

6. Caricature (caricatures related to social studies materials),

7. Humor (Stories containing aspects of humor),

8. Controversy and contemporary issues (linking history with contemporary events),

9. If History (a question that examines students' critical power by asking students to explain historical events opposed to actual events),

10. Memorizing strategies.

\section{REFERENCES}

[1] A. Prastowo, Bahan Ajar Inovatif, Yogyakarta: Diva Press, 2011

[2] N. Supriatna, Rekontruksi Pembelajaran Sejarah Kritis. Historia Utama Press. Bandung, 2007

[3] S. H. Hasan, Pendidikan Sejarah Indonesia: Isu dan dalam Ide dan Pembelajaran, Bandung: Rizki Ofset, 2012

[4] B. Given, Brain Based Teaching, Bandung: Mizan Media utama, 2007.

[5] E. Jansen, Brain Based Learning: Pembelajaran Berbasis Kemampuan Otak. Yogyakarta: Pustaka Pelajar, 2008

[6] W.R. Borg and M.D. Gall, Educational research. An introduction (5th ed.), White Plains, NY: Longman, 1989.

[7] T. Buzan, Mind Map, Jakarta: Pustaka Al Kaustar, 2009. 